\title{
Preparation and characterization of boron-based bioglass by sol -gel process
}

\author{
Roberto Gustavo Furlan ${ }^{1}$ - Wagner Raphael Correr $^{2,3}$ - Ana Flavia Costa Russi ${ }^{1}$ Mônica Rosas da Costa lemma ${ }^{1}$. \\ Eliane Trovatti $\mathbb{D}^{1} \cdot$ Édison Pecoraro ${ }^{4}$
}

Received: 9 July 2018 / Accepted: 3 September 2018 / Published online: 13 September 2018

(c) Springer Science+Business Media, LLC, part of Springer Nature 2018

\begin{abstract}
45S5 bioglass has been widely studied in the last few decades because of its bioactivity and promising applications in the biomedical field. Boron, even few studied, represents a potential element to improve the properties of the 45S5 bioglass derivatives. The bioglasses are conventionally prepared by heat treatment of oxides and silicon. Here, the sol-gel method is proposed for the preparation of the boron-based 45S5 bioglass (45S5B) and the classical 45S5 bioglass (45S5), using watersoluble salts as raw materials. The bioglasses were characterized by FTIR, XRD, and SEM, indicating the success of the sol - gel method for preparation of the samples. The bioglasses were also tested in vitro for bioactivity in biological conditions and cytotoxicity against eukaryotic cells. The bioactivity of 45S5B was similar to the bioactivity of $45 \mathrm{~S} 5$ bioglass, indicated by the deposition of hydroxyapatite crystals at the surface of the pristine bioglasses. The results of cytotoxicity tests revealed that the $\mathrm{IC}_{50}$ of $45 \mathrm{~S} 5 \mathrm{~B}\left(\mathrm{IC}_{50}=7.56 \mathrm{mg} \mathrm{mL}^{-1}\right)$ was similar to the $\mathrm{IC}_{50}$ of $45 \mathrm{~S} 5\left(\mathrm{IC}_{50}=8.15 \mathrm{mg} \mathrm{mL}^{-1}\right)$, indicating its safety for application in the biomedical field.
\end{abstract}

\section{Graphical Abstract}

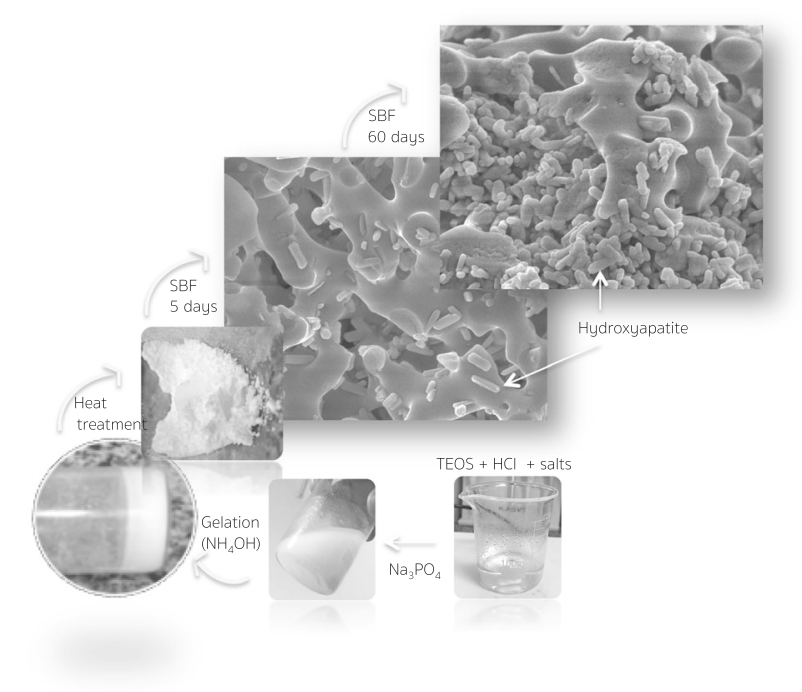

Eliane Trovatti

elianetrov@yahoo.com.br

1 University of Araraquara-UNIARA, Rua Carlos Gomes, 1217, Araraquara, SP 14801-340, Brazil

2 Centre d'Optique, Photonique et Laser, Université Laval, 2375 rue de la Terrasse, Québec, QC G1V 0A6, Canada

3 Instituto de Física de São Carlos, Universidade de São Paulo, São Carlos, SP, Brazil

4 Institute of Chemistry, UNESP — São Paulo State University, Araraquara, SP 14800-060, Brazil 


\section{Highlights}

- The sol-gel process was used to prepare boron-based bioglass from water-soluble salts.

- The bioactivity of the boron-based bioglass was similar to the conventional bioglass.

- The boron-based bioglass and 45S5 bioglass showed high in vitro bioactivity.

- The boron-based bioglass was not cytotoxic against OSTEO-1 eukaryotic cells.

Keywords Boron $\cdot 45 \mathrm{~S} 5 \cdot$ Bioglass $\cdot$ Cytotoxicity $\cdot$ in vitro $\cdot$ OSTEO-1 cells

\section{Introduction}

The increased human average age and lifestyle are associated with the increasing health problems, normally leading tissues such as bones, cartilage, and tendons to injuries [1]. The search for improved life quality has been boosting the research and development of new materials to repair damaged tissues. The technologies and materials for bone augmentation have benefited patients and represent a clinical routine nowadays, with a large range of commercially available biomaterials, including mainly the animal derivatives (bovine-treated bone) [2] and the synthetic hydroxyapatites [3]. These temporary bone substitutes are used for filling lesions in which the loss of bone is high, but capable of repairing itself. The material fills the lesion and allows cell migration and proliferation, giving rise to pristine bone formation leading to in situ bone augmentation and ensuring the mechanical strength for the implant, in the healing process of about $6-10$ months [4].

The bone augmentation materials for dental implants represent a growing market. The most fashion bone substitutes in clinical procedures for teeth implantation are used in the form of powder [5]. The demineralized bovine bone is widely used for clinical applications; however, its heterologous origin may represent a problem in the near future $[5,6]$, once animal derivatives tend to be avoided for human implants. The synthetic hydroxyapatites do not show adequate performance when compared to the bovine bone and the problematic refers to the low performance in loadbearing applications mainly because it is brittle, exacerbated by its rate of biodegradability, and in general slow because of its high crystallinity degree [7].

Apart from apatites, synthetic bioactive glasses have also been studied for bone healing. Bioglasses are in general brittle, and its main presentation is in the form of powder, not self-sustainable, a property that can be explored for filling small bone lesions, such as its use in oral bone augmentation, once these filling materials are not subject to high mechanical loading. 45S5 bioglass, synthesized in 1970 [8], is a bioactive glass based on silica, biocompatible, and capable of giving rise to hydroxyapatite in situ, in physiological conditions. The 45S5 formulation has been modified aiming to improve the properties of their derivatives [9], such as NovaBone, NovaMin, NovaThera, and
PerioGlass [9]. Silicate-based bioactive glasses associated with Fe [10], yttria-zirconia [11], and graphene oxide [12], have been proposed and investigated. Besides, all these formulations represent available products in the market, the need of synthetic biomaterials that behave adequately within the human body and stimulate the bone augmentation encourages further studies, and the development of alternative materials. In this vein, boron represents an interesting chemical element capable of improving the properties of bioglasses. Boron improves the mechanical properties of glasses, especially phosphate glasses and its susceptibility to hydrolysis by the formation of $\mathrm{B}-\mathrm{OH}$ bonds in water, which catalyze the bioactivity of its derivatives [13-18]. The borate glasses (free of silica) represent a good substrate for cell adhesion, proliferation, and differentiation $[16,19]$ in vivo [20] and are capable of inducing the angiogenesis [21] and neovascularization [14, 15]. Only few reports can be found in the literature for the preparation of silica-based bioactive bioglasses associated with boron [15, 22-24]. An interesting example is the silica bioglass $45 \mathrm{~S} 5$ plus $2 \mathrm{wt} \%$ boron, in which boron replaces silica, resulting in a material capable of increasing the angiogenesis in in vitro tests using an embryonic quail chorioallantoic membrane [23]. Further investigations are necessary to increase the range of boron-silicate-based bioactive glasses [25] and also the technologies for their development, aiming to improve the processing and quality of these materials.

Regarding the synthesis, the sol-gel process represents an interesting alternative for preparation of bioglasses in which the structure (including crystallinity) and morphology can be easily controlled when compared to the melt quenching process because of the low temperature for thermal treatment. Also, the sol-gel process generates materials with high homogeneity and purity [15, 26]. Encouraged by the demand for 45S5 derivatives for use in the biomedical field, here, we propose the use of sol-gel process and water- soluble salts to prepare the boron-based $45 \mathrm{~S} 5$ bioglass and to compare its properties to 45S5 also prepared from water-soluble salts and sol-gel process. The details of the preparation method and the structural characterization (Fourier-transform infrared spectroscopy (FTIR) and XRD), morphology (scanning electron microscopy (SEM)), bioactivity and biodegradation in in vitro 
physiological conditions, and in vitro cytotoxicity are described.

\section{Materials and methods}

\subsection{Materials}

The salts calcium chloride $\left(\mathrm{CaCl}_{2 \cdot 2} \mathrm{H}_{2} \mathrm{O}\right)$, sodium phosphate tribasic dodecahydrate $\left(\mathrm{Na}_{3} \mathrm{PO}_{4} .12 \quad \mathrm{H}_{2} \mathrm{O}\right)$, boric acid $\left(\mathrm{H}_{3} \mathrm{BO}_{3}\right)$, sodium chloride $(\mathrm{NaCl})$, potassium chloride $(\mathrm{KCl})$, magnesium chloride $\left(\mathrm{MgCl}_{2} \cdot 6 \mathrm{H}_{2} \mathrm{O}\right)$, sodium hydrogencarbonate $\left(\mathrm{NaHCO}_{3}\right)$, dipotassium hydrogen phosphate trihydrate $\left(\mathrm{K}_{2} \mathrm{HPO}_{4} \cdot 3 \mathrm{H}_{2} \mathrm{O}\right)$, ethanol, hydrochloric acid $(\mathrm{HCl})$, ammonium hydroxide $\left(\mathrm{NH}_{4} \mathrm{OH}\right)$, and dimethylsulfoxide (DMSO) were purchased from Synth (Brazil); tetraethylorthosilicate (TEOS), sodium sulfate anhydrous $\left(\mathrm{Na}_{2} \mathrm{SO}_{4}\right)$, and tris(hydroxymethyl)aminomethane $\left(\mathrm{NH}_{2} \mathrm{C}\right.$ $\left.\left(\mathrm{CH}_{2} \mathrm{OH}\right)_{3}\right)$ were purchased from Sigma Aldrich USA. Dulbecco's modified Eagle's medium (DMEM) and fetal bovine serum were purchased from Cultilab (Brazil), 3-(4,5dimethylthiazol-2-yl)-2,5-diphenyltetrazolium salt (MTT) was purchased from Merck (US), isopropyl alcohol and phosphate-buffered saline (PBS) were purchased from Synth (Brazil), and trypsin was sourced from Gibco (US). All solvents and reagents (analytical grade) were used as purchased. Osteo1 cells (calvarium rat cells) were provided by Prof. Selistre de Araújo, LBBM laboratory, UFscar, Sao Carlos, Brazil.

\subsection{Sample composition and preparation}

The bioactive glasses were prepared by sol-gel method. For $45 \mathrm{~S} 5, \mathrm{NaCl}(3.9 \mathrm{~g})$ was dissolved in $5 \mathrm{~mL}$ of deionized water and added into TEOS:ethanol solution (16.8 $\mathrm{mL}: 16.5 \mathrm{~mL}$ ) under magnetic stirring at room temperature, followed by addition of the $\mathrm{HCl}$ solution (0.6 M, 900 $\mu \mathrm{L})$. The flask was stirred for $15 \mathrm{~min}$ after TEOS hydrolysis. $\mathrm{CaCl}_{2} \cdot 2 \mathrm{H}_{2} \mathrm{O}$ and $\mathrm{Na}_{3} \mathrm{PO}_{4} \cdot 12 \mathrm{H}_{2} \mathrm{O}$ (1.6 g) were dissolved in $7.5 \mathrm{~mL}$ of deionized water and added to TEOS solution. The $\mathrm{pH}$ was increased to $5( \pm 0.5)$ with $\mathrm{NH}_{4} \mathrm{OH}$ $(3 \mathrm{~mL})$ and rest to condensation (about $30 \mathrm{~min}$ ). The gel was kept sealed for 1 week and then dried at room temperature. The thermal treatment was carried out at $700{ }^{\circ} \mathrm{C}$ for $3 \mathrm{~h}$ by heating at $10^{\circ} \mathrm{C} / \mathrm{min}$ using a microprocessed furnace EDG (3000-10P, Tecnal, Brazil). The dried powder was milled using a mortar. A similar procedure was used for the preparation of $45 \mathrm{~S} 5 \mathrm{~B}$; however, the volume of water was increased because of the low solubility of boric acid $(0.2 \mathrm{~g})$, which was dissolved in $10 \mathrm{~mL}$ of deionized water and added to the suspension before addition of $\mathrm{NH}_{4} \mathrm{OH}$.

\subsection{Characterization}

\subsubsection{In vitro bioactivity}

The in vitro bioactivity was studied by immersion of 100 $\mathrm{mg}$ of each sample in $25 \mathrm{~mL}$ of simulated body fluid (SBF) solutions for 60 days at $37^{\circ} \mathrm{C}$, followed by measurement of mass variation (gain or loss of mass), SEM, and FTIR. SBF solution was prepared according to the formula described by Kokubo [19]. Shortly, the salts $\mathrm{NaCl}(8 \mathrm{~g}), \mathrm{NaHCO}_{3}$ $(0.35 \mathrm{~g}), \mathrm{KCl}(0.22 \mathrm{~g}), \mathrm{K}_{2} \mathrm{HPO}_{4} \cdot 3 \mathrm{H}_{2} \mathrm{O}(0.23 \mathrm{~g}), \mathrm{MgCl}_{2}$ $.6 \mathrm{H}_{2} \mathrm{O}(0.3 \mathrm{~g}), \mathrm{CaCl}_{2}(0.28 \mathrm{~g})$, and $\mathrm{Na}_{2} \mathrm{SO}_{4}(0.07 \mathrm{~g})$, tris (hydroxymethyl)aminomethane $(6.04 \mathrm{~g})$ were dissolved in deionized water at $37^{\circ} \mathrm{C}$ and $1 \mathrm{M}$ hydrochloric acid was added until reaching $\mathrm{pH}$ 7.40. Samples were withdrawn at $0.3,1,2,5,7,15,30,45$, and 60 days. Two samples were used for each immersion time. After removal of the SBF solution, samples were centrifuged with deionized water and dried at $60{ }^{\circ} \mathrm{C}$ until constant mass. For bioactivity evaluation, the formation of the carbonated hydroxy calcium phosphate at the surface of the samples was assessed by scanning electron microscopy (SEM) and FTIR. The loss or gain of mass was measured to determine the rate of the conversion (bioactivity) and calculated in the following equation:

$$
W(\%)=\left[\left(W_{0}-W_{\mathrm{f}}\right) / W_{0}\right],
$$

where $W_{0}$ is the initial mass of the materials and the $W_{\mathrm{f}}$ is the final mass.

Furthermore, the $\mathrm{pH}$ of the SBF medium in which samples were immersed was monitored on the $0,7,15,30$, 45 , and 60th day.

\subsubsection{Scanning electron microscopy}

SEM images were assessed using a scanning electron microscope model Sigma (Zeiss, Germany). The samples withdrawn from in vitro bioactivity experiment were dried and sputter-coated with platinum (Q-150RS, Quorum Technologies).

\subsubsection{FTIR}

FTIR transmittance spectra were recorded at room temperature, from 4000 to $600 \mathrm{~cm}^{-1}$ and 16 scans were averaged using a PerkinElmer Spectrum 100 spectrometer equipped with an attenuated total reflection (ATR) accessory for structural analysis.

\subsubsection{XRD}

An Ultima IV (Rigaku, Japan) X-ray diffractometer was used to study the crystallinity and phase composition of the 
Fig. 1 Digital photographs following the sol-gel preparation process of $45 \mathrm{~S} 5$, showing the liquid mixture a, the gelled mixture $\mathbf{b}$, and the heat-treated bioglass powder $\mathbf{c}$, and for 45S5B showing the liquid sol-gel mixture d, the gelled mixture $\mathbf{e}$, and the heattreated bioglass powder $\mathbf{f}$
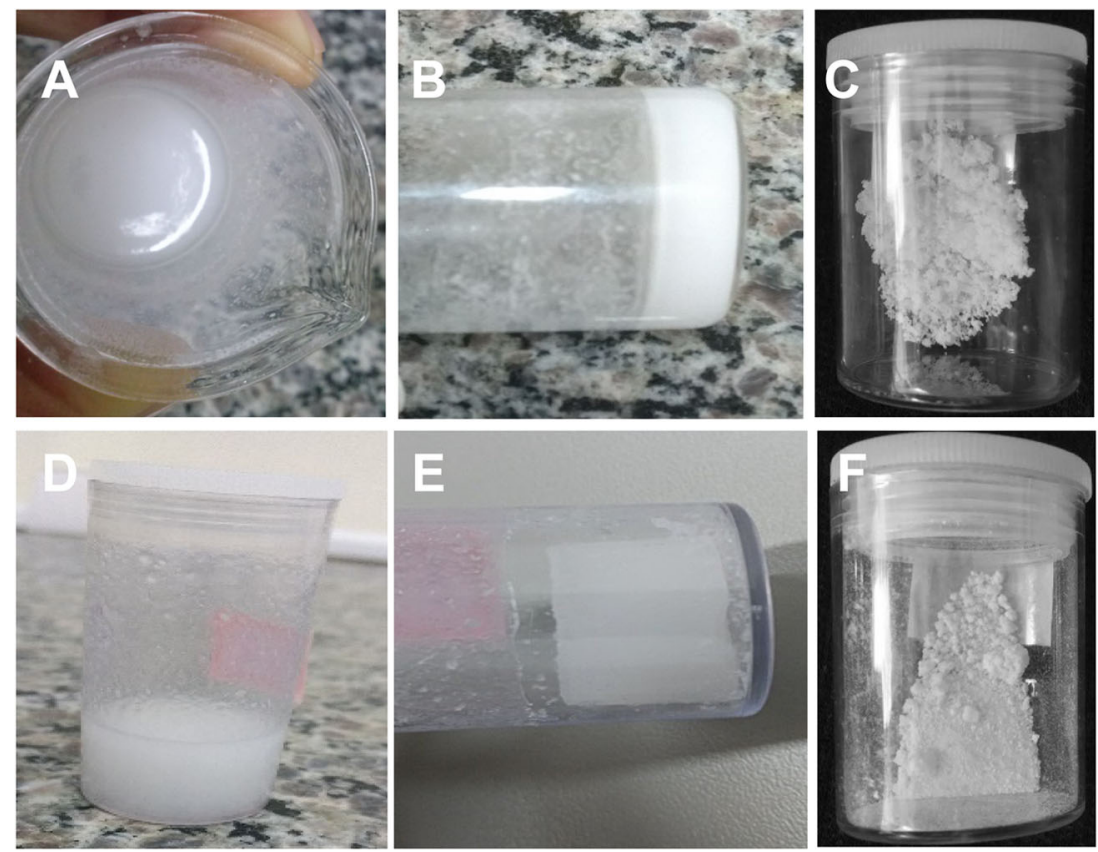

samples. XRD patterns were recorded at Bragg-Brentano configuration in the $2 \theta$ range of $20-80^{\circ}$, step size of $0.02^{\circ}$, using a $\mathrm{Cu} \mathrm{K} \alpha$ radiation, and $40 \mathrm{kV}$ operating voltage and $40 \mathrm{~mA}$ current.

\subsubsection{Cytotoxicity tests}

2.3.5.1 Sample extract Two-hundred milligrams of $45 \mathrm{~S} 5$ or $45 \mathrm{~S} 5 \mathrm{~B}$ were extracted in $1 \mathrm{~mL}$ of DMEM for $24 \mathrm{~h}$, at room temperature, following ISO10993-5.

2.3.5.2 Cell culture The osteogenic cells from lineage OSTOE-1 (rat calvarium) were grown in DMEM supplemented with fetal calf serum $(10 \% \mathrm{v})$ and antibiotics (penicillin $100 \mathrm{U} / \mathrm{mL}$; streptomycin $0.1 \mathrm{mg} \mathrm{mL}^{-1}$ ). The cultures were maintained at $37 \pm 2{ }^{\circ} \mathrm{C}$ in $5 \% \quad \mathrm{CO}_{2}$ atmosphere and, when in confluence of $80-90 \%$ they were trypsinized. Trypsin was neutralized by addition of DMEM with fetal calf serum. The cells were used for the cytotoxicity test.

2.3.5.3 Powder extraction The liquid extract for the cytotoxicity tests was prepared using $200 \mathrm{mg} \mathrm{mL}^{-1}$ of $45 \mathrm{~S} 5$ or 45S5B in DMEM culture medium at room temperature, for $24 \mathrm{~h}$. The extract was separated from the bioglass by centrifugation at $1 \times g$ for $2 \mathrm{~min}$ and used as such. All the steps were performed in sterile conditions.

2.3.5.4 Cytotoxicity test The cytotoxic effect of the samples was assessed by MTT assay (ISO 10993-5). As such, the cell suspension was centrifuged for $3 \mathrm{~min}$ at $1200 \times g$, and transferred to a 96-well plate in a cell density of $1 \times 10^{4}$ cells/well. The 96-well plates were incubated for $24 \mathrm{~h}$ for complete cell adhesion. Later, the cells were treated with $100 \mu \mathrm{L}$ of positive control (100\% v, DMSO), $100 \mu \mathrm{L}$ of negative control (DMEM), and $100 \mu \mathrm{L}$ of the extracts from $45 \mathrm{~S} 5$ or $45 \mathrm{~S} 5 \mathrm{~B}$ at $200,100,80,40,20,10,5,2.5,1.25$, and $0.63 \mathrm{mg} \mathrm{mL}^{-1}$ in DMEM. After $48 \mathrm{~h}$, the suspension was removed and the plates were washed with PBS. Onehundred microliters of MTT $\left(1 \mathrm{mg} \mathrm{mL}^{-1}\right.$ in PBS) was added to each well. The microplates were incubated at $37 \pm 2{ }^{\circ} \mathrm{C}$ for $4 \mathrm{~h}$, protected from light. These steps were performed in sterile conditions. The formazan crystals were solubilized by adding $50 \mu \mathrm{L}$ of DMSO/well. The absorbance was read at $570 \mathrm{~nm}$ in a Bio-Rad Model550 spectrophotometer. The cytotoxicity assays were performed in triplicate. The percentage of viable cells was calculated regarding the negative control and represents the cytotoxicity of each treatment, as follows: $\%$ of cell viability $=[(\mathrm{ABS}$ of negative control ABS of PIL-treated samples) / (ABS of negative control) $\times$ 100].

\section{Results and discussion}

The polycondensation reaction of the sol-gel process generated a gelled material as shown in Fig. 1a, d for 45S5 and $45 \mathrm{~S} 5 \mathrm{~B}$, respectively, and no large agglomerates were observed. The drying led the materials to contract and decrease the volume (Fig. 1b, e), and the thermal treatment generated the powders shown in Fig. 1c, f. For both materials, the addition of the $\mathrm{Na}_{3} \mathrm{PO}_{4}$ led to a fast increase of the viscosity, which can be attributed to the polyphosphate chain network favoring the system stability (no phase 
A

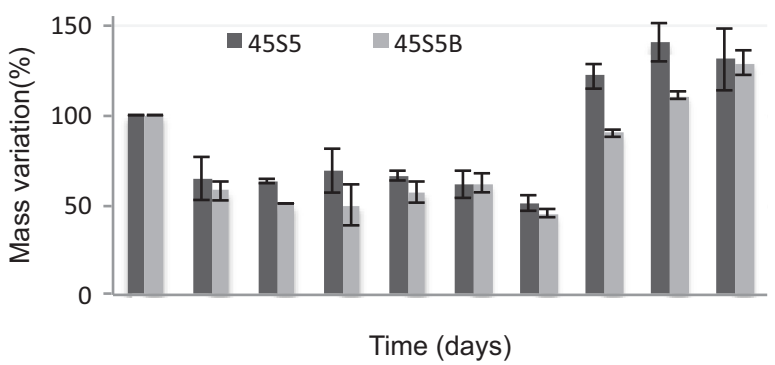

B

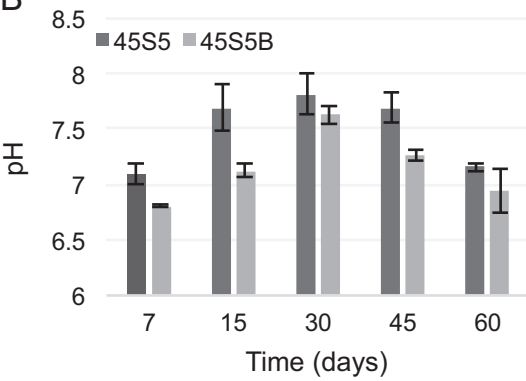

Fig. 2 Mass variation (\%) of bioglasses 45S5 and 45S5B after immersion in SBF solution a, and the changes in SBF solution pH after contact with $45 \mathrm{~S} 5$ or $45 \mathrm{~S} 5 \mathrm{~B}$ b

separation) up to the gelation. The increased viscosity contributed to increase the homogeneity of the material, once they avoid phase separation up to drying.

\subsection{In vitro bioactivity}

The bioactivity of the materials was investigated up to 60 days in SBF. The changes in initial mass, ATR-FTIR spectroscopy, SEM, and XRD indicated the formation of hydroxyapatite.

The mass change of the samples was measured at 0 and $8 \mathrm{~h}, 1,3,5,7,15,30,45$, and 60 days time point, and the results are shown in Fig. 2. The bioglasses showed a fast loss of mass up to 8-h time point, about 25 and $40 \mathrm{wt} \%$ for 45S5 and 45S5B, respectively. Then, the mass was kept constant up to 15-days time point. The loss of mass can be attributed to the dissolution of the soluble salts in SBF and the maintenance of the mass can be possibly caused by the equilibrium between the dissolution of salts and the formation/deposition of hydroxyapatite at the surface of the bioglasses particles. After 15-days time point, the mass dramatically increased up to 60-days time point, reaching about $50 \mathrm{wt} \%$ gain. This result can be attributed to the strong bioactivity feature of the bioglasses in SBF, in which the salts from the liquid medium (SBF) clearly shifted the equilibrium preferentially toward the formation of hydroxyapatite, favored by the exchange of SBF, the source of salts, improving the dynamics of the formation of hydroxyapatite. The bioactivity of $45 \mathrm{~S} 5$ was slightly higher than 45S5B after 30-days time point.

The variation of SBF pH after 7, 15, 30, 45, and 60 days in contact with the bioglasses is shown in Fig. 2b. The $\mathrm{pH}$ of SBF was 7.4 at the beginning and its general behavior for both $45 \mathrm{~S} 5$ and 45S5B slightly increases up to 30-days time point, followed by a decrease of $\mathrm{pH}$ values up to 60 days, but the variation was kept within the $\mathrm{pH}$ range of 6.5 and 8.0. The variation of $\mathrm{pH}$ is attributed to the hydrolysis of the salts in its pristine state and their corresponding oxides, generated by thermal treatment. The increase in $\mathrm{pH}$ values is because of the dissociation of salts such as sodium and calcium in aqueous liquid medium. 45S5 exchanges $\mathrm{Ca}^{2+}$ and $\mathrm{Na}^{+}$with the protons from SBF. The replacement of $\mathrm{H}^{+}$ from $\mathrm{SBF}$ by $\mathrm{Ca}^{2+}$ or $\mathrm{Na}^{+}$leads to the increase in $\mathrm{pH}$ values because of the decrease of the dissociated protons. Also, the formation of the hydroxyapatite results from the ion exchange between the bioglass and the SBF; thus, the variation of $\mathrm{pH}$ values indicates the formation of hydroxyapatite. The $\mathrm{pH}$ of the 45S5B was lower than the 45S5 in all time points, possibly because of the hydrolysis of boron oxide leading to the formation of boron acid derivatives. The variation of $\mathrm{pH}$ was low because the SBF was used in large excess when compared to the small amount of bioglass in an attempt to simulate the body fluid dynamics. The salts were capable of keeping the $\mathrm{pH}$ range adequate for cell growth and development.

\subsection{FTIR}

The FTIR of 45S5 (Fig. 3) before immersion in SBF shows the typical spectrum of silicate-based bioglasses with the main peaks at 1100 and $3375 \mathrm{~cm}^{-1}$ related to $\mathrm{Si}-\mathrm{O}$ stretching and the overlapping of $\mathrm{OH}$ vibration from silanol and adsorbed water. The weak peak at $800 \mathrm{~cm}^{-1}$ is related to $\mathrm{Si}-\mathrm{O}$ bending, and the peak at $900 \mathrm{~cm}^{-1}$ corresponds to the $\mathrm{Si}-\mathrm{O}$ with one nonbridging oxygen. The peak at about $1635 \mathrm{~cm}^{-1}$ corresponds to molecular water $(\mathrm{H}-\mathrm{O}-\mathrm{H}$ scissoring). After immersion in SBF, the peaks of 45S5 spectra changed dramatically, revealing changes in its structure. The spectrum of $45 \mathrm{~S} 5$ immersed for $8 \mathrm{~h}$ in SBF showed the appearance of the peak at about $650 \mathrm{~cm}^{-1}$, indicating the formation of hydroxyapatite [27]. The disappearance of the peak at $900 \mathrm{~cm}^{-1}$ related to $\mathrm{Si}-\mathrm{O}$ with one nonbridging oxygen and the appearance of the peak at $3180 \mathrm{~cm}^{-1}$ can be related to changes in the structure of the $\mathrm{OH}$ groups from $\mathrm{Si}$ $-\mathrm{OH}$, possibly related to the formation of $\mathrm{Si}-\mathrm{O}^{-} \mathrm{Na}^{+}$. The disappearance of the peaks at 3400 and $1635 \mathrm{~cm}^{-1}$ indicates the loss of water and the bonding of $\mathrm{OH}$ from $\mathrm{Si}-\mathrm{OH}$ to the salts from SBF, such as sodium, forming structures such as 

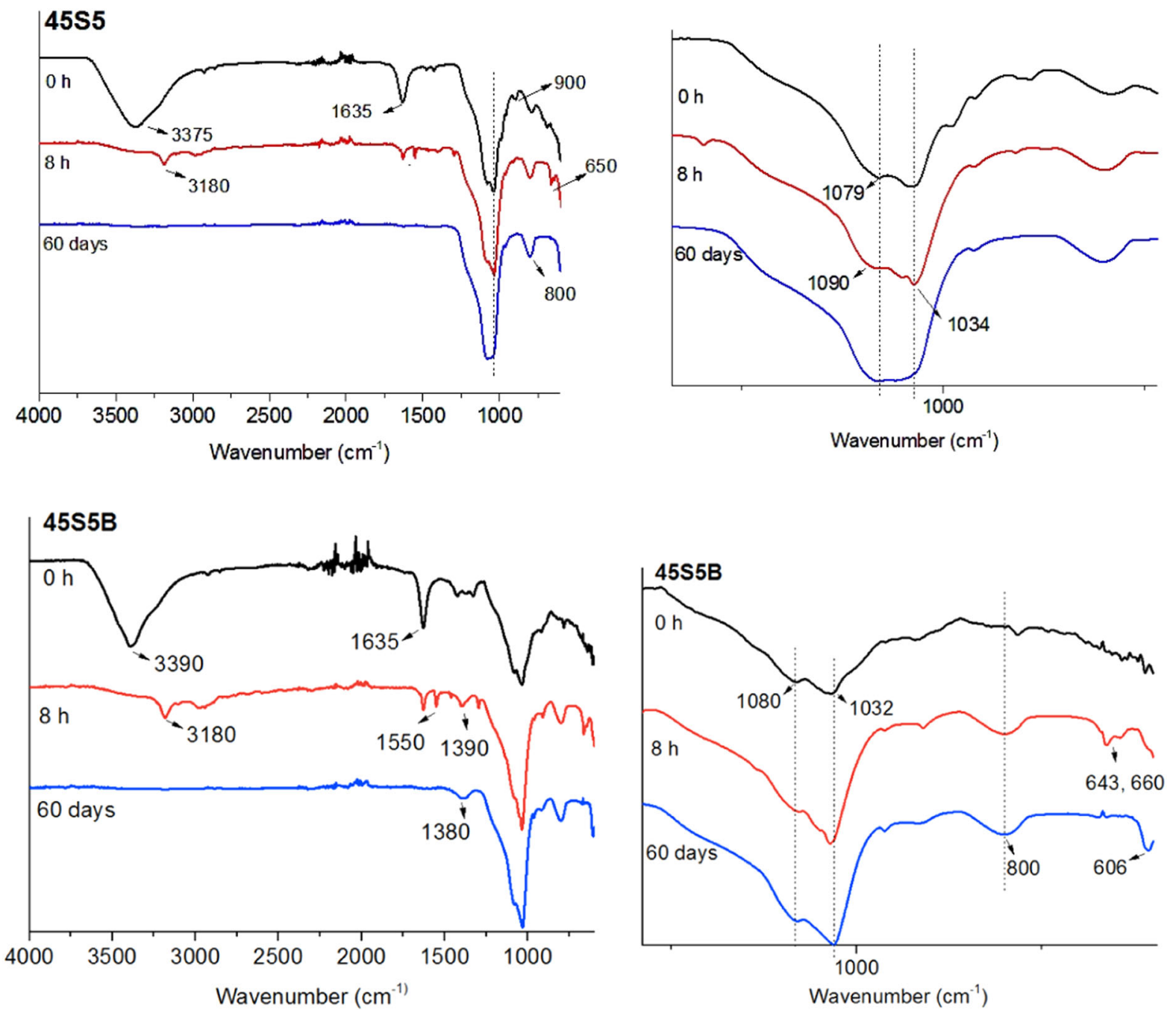

Fig. 3 FTIR-ATR results of $45 \mathrm{~S} 5$ and 45S5B before immersion in SBF $(0 \mathrm{~h})$, and after $8 \mathrm{~h}$ and 60 days of immersion in SBF

Si-O-Na. After 60 days of immersion, only the peaks at 1034 and 1090 were found, indicating deep changes in the siloxane-based structure evidenced by the enlargement of the $\mathrm{Si}-\mathrm{O}$ vibration peak. The phosphate contributions, at about $1000-1100 \mathrm{~cm}^{-1}$, are mostly overlapped by the silicate peaks and are not separated as individual infrared vibrations; however, the changes at this region of the spectrum can be attributed to $\mathrm{P}=\mathrm{O}$ vibrations of the phosphate group from hydroxyapatite [22].

45S5B FTIR spectrum (Fig. 3) shows similar vibration peaks of the chemical groups of $45 \mathrm{~S} 5$, as expected, once most of the components do not change, except the inclusion of boron in 45S5B formulation. Nevertheless, boron vibration peaks are clearly shown in 45S5B spectrum. The typical borate vibration peaks are related to boron triangular (BO3) or tetrahedral (BO4) structures from diborates, pertaborates, and triborates [28, 29]. The tetrahedral borate shows asymmetric stretching vibrations in the range of 800 $1200 \mathrm{~cm}^{-1}$ [30], which appears in Fig. $3 \mathrm{~b}$ at about $1032 \mathrm{~cm}$ -1 , overlapped with the $\mathrm{Si}-\mathrm{O}$ vibration peak. The frequency absorption of a triangular borate structure $\left(\mathrm{BO}_{3}\right.$ and $\mathrm{BO}_{2} \mathrm{O}$ ) appears at about $1200-1550 \mathrm{~cm}^{-1}$ and is evidenced in Fig. 3b by the absorption bands at $1350-1400 \mathrm{~cm}^{-1}$ and the bending vibrations or deformation modes of borate appeared at $700 \mathrm{~cm}^{-1}$ [30]. The immersion in SBF for $8 \mathrm{~h}$ revealed deep changes in the spectrum clearly related to the formation of hydroxyapatite evidenced by the appearing of the double peaks at 643 and $660 \mathrm{~cm}^{-1}$, as described for 45S5. In addition, the resonances attributed to the siloxane glass network $(\mathrm{Si}-\mathrm{O})$ weakened and the absorption vibrations related to the phosphate group $(\mathrm{P}=\mathrm{O})$, at about 1032 $\mathrm{cm}^{-1}$ led to deep changes at this dominant region of the spectrum [22]. The vibrations at $1390 \mathrm{~cm}^{-1}$ can be attributed to $\mathrm{B}-\mathrm{O}$ derivative bonds. 

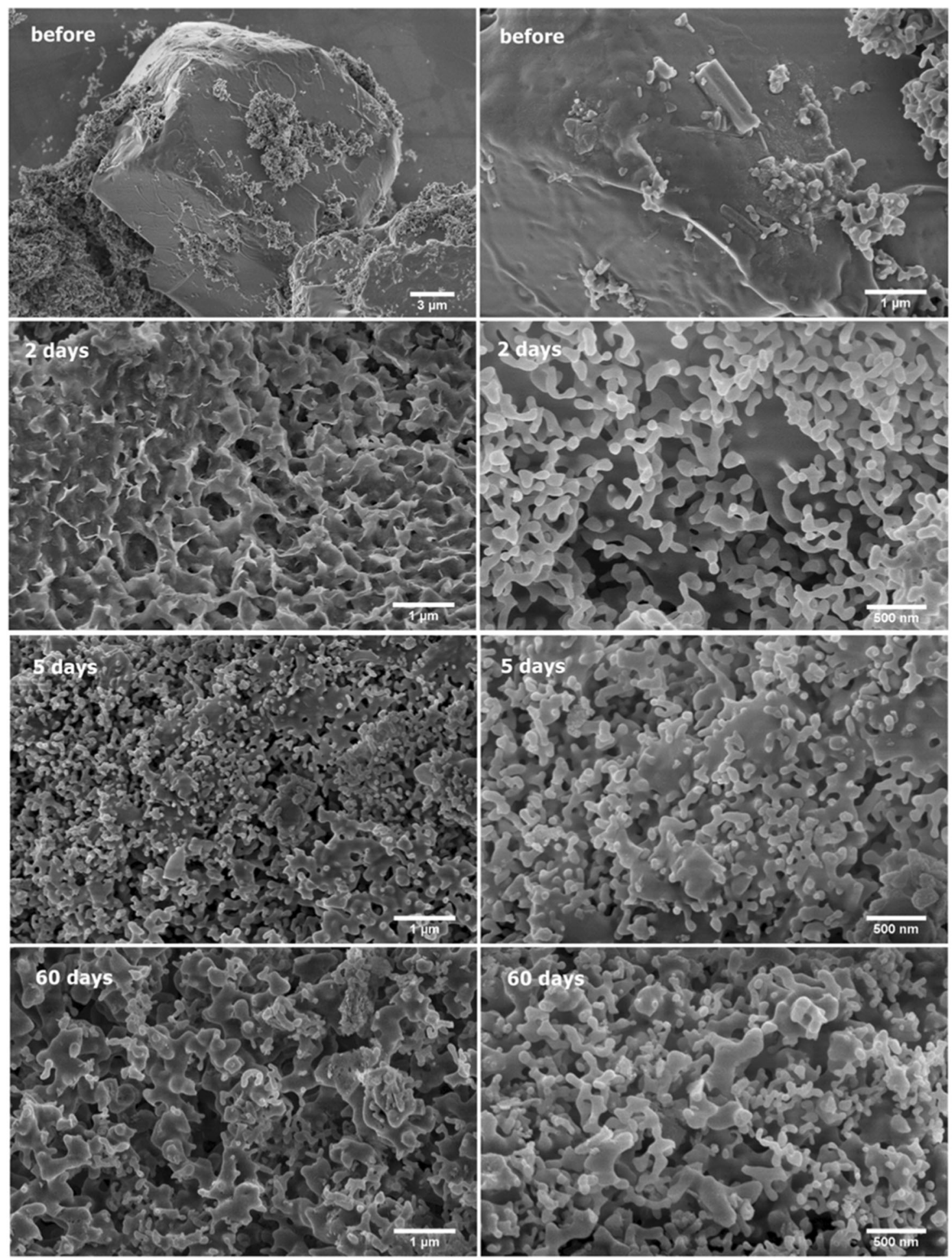

Fig. 4 SEM images of $45 \mathrm{~S} 5$ before immersion in SBF and after 2 days, 5 days and 60 days in SBF. Scale bars $=1 \mu \mathrm{m}$ at left, and $500 \mathrm{~nm}$ at right

\subsection{SEM}

Figures 4 and 5 show the SEM images of 45S5 and 45S5B, respectively in function of time in SBF. Sol-gel processing generated particles with smooth surfaces, as shown in Figs.
$4 a, b$ and $5 a, b$. The structure of the bioglasses drastically changed in SBF, starting by the corrosion of the particles caused by the dissolution of salts into the liquid medium, followed by the precipitation of hydroxyapatite crystals at the surface of $45 \mathrm{~S} 5$ and $45 \mathrm{~S} 5 \mathrm{~B}$. The immersion of $45 \mathrm{~S} 5$ in 

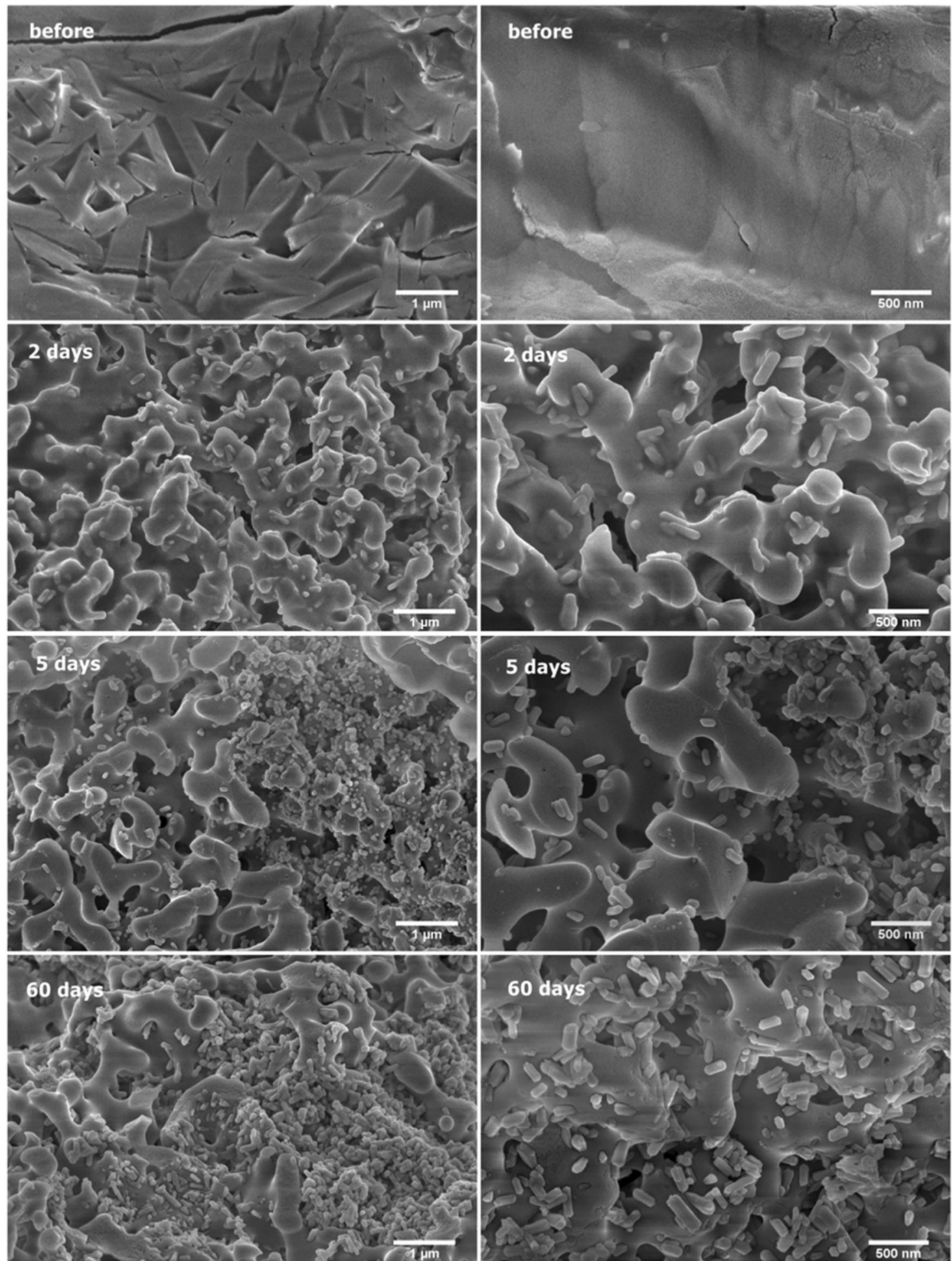

Fig. 5 SEM images of 45S5B before immersion in SBF and after 2 days, 5 days, and 60 days in SBF in two magnifications, scale bars $=1 \mu \mathrm{m}$ at left and $500 \mathrm{~nm}$ at right

SBF for $8 \mathrm{~h}$ gave rise to pores at its surface and a huge amount of small precipitated crystals, which can be seen at the higher magnification. The growth of crystals increased with time, as shown in Fig. 4e-h, as well the size and number of pores, evidenced in Fig. 4g, h. The large number of pores indicates the dissolution of salts into the medium, leading to a loss of mass of the bioglass; otherwise, the formation of hydroxyapatite at the surface of the bioglasses 
increases their mass. The SEM images confirm the results of mass changes shown in Fig. 2. The behavior of 45S5B was quite similar to 45S5; however, the morphology of 45S5B was slightly different, showing larger formers and larger pores when compared to 45S5. Interestingly, the structures of hydroxyapatite crystals showed a similar morphology for both bioglasses, as well the pattern of deposition at the surface of the bioglasses, showing similar sizes and shapes.

\subsection{XRD}

Figure 6 shows the XRD diffractograms of 45S5 and 45S5B before and after immersion in SBF for 60 days. In general, the results revealed the deposition of hydroxyapatite at the surface of both the bioglasses, in total agreement with the results of SEM and loss/gain of mass. The $2 \theta$ XRD patterns of the standard hydroxyapatite are shown in Table 1 [22], as well the experimental data of 45S5 and 45S5B after 60 days of immersion in SBF. The peaks at $2 \theta=31.29^{\circ}$ and $31.19^{\circ}$ displayed at 45S5 and 45S5B diffractograms, respectively, correspond to $2 \theta=31.74^{\circ}$ of the standard hydroxyapatite, and the peaks at $32.24^{\circ}$, corresponding to the (002) crystal plane are typical peaks of hydroxyapatite [31]. The characteristic peaks of hydroxyapatite identified in 45S5 and 45S5B are displayed in Table 1 [31]. The XRD diffractogram of 45S5 and 45S5B before immersion in SBF revealed the presence of the amorphous peak at $22^{\circ}$ corresponding to $\mathrm{SiOH}$ and the crystalline peaks attributed to $\mathrm{NaCl}$ formed in

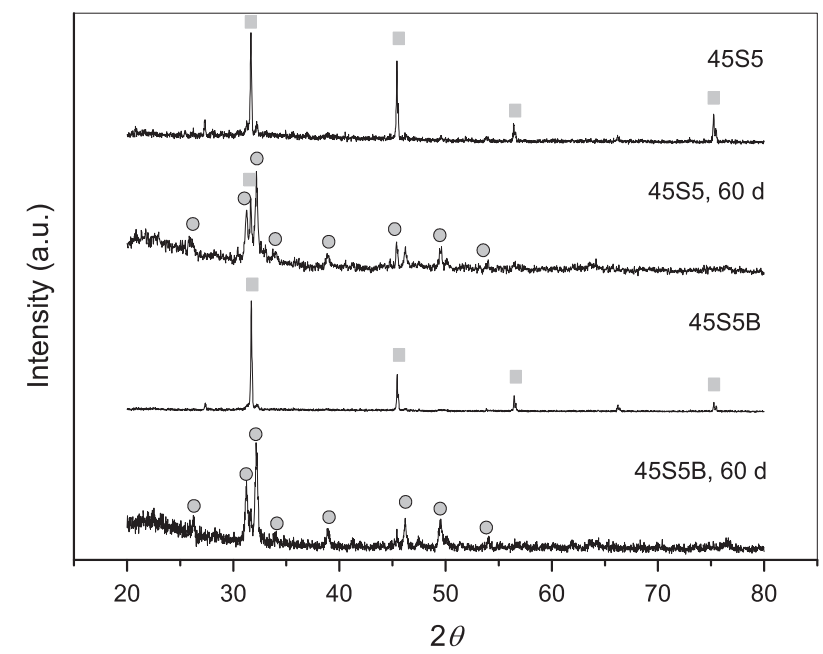

Fig. 6 XRD diffractograms of $45 \mathrm{~S} 5$ and $45 \mathrm{~S} 5 \mathrm{~B}$ before and after immersion in SBF for 60 days, showing the typical hydroxyapatite peaks ("๑”) and $\mathrm{NaCl}$ (“" ")

Table 1 The parameters of 2 theta (hkl) for hydroxyapatite pattern and the experimental values for $45 \mathrm{~S} 5$ and $45 \mathrm{~S} 5 \mathrm{~B}$ after $60 \mathrm{~h}$ of immersion in SBF

\begin{tabular}{llllllllll}
\hline (hkl) & $(002)$ & $(211)$ & $(112)$ & $(300)$ & $(202)$ & $(310)$ & $(222)$ & $(213)$ & $(004)$ \\
Pattern [31] & 25.80 & 31.74 & 32.13 & 32.85 & 34.08 & 39.81 & 46.71 & 49.41 & 53.1 \\
45S5 & 25.96 & 31.29 & 31.74 & 32.24 & 34.14 & 39.90 & 46.21 & 49.61 & 53.92 \\
45S5B & 26.30 & 31.19 & 31.74 & 32.24 & 34.02 & 39.94 & 46.19 & 49.52 & 54.15 \\
\hline
\end{tabular}

the precipitation process. The peaks at $31.74^{\circ}, 45.40^{\circ}$, $56.50^{\circ}$, and $75.18^{\circ}$ corresponded to $200,220,222$, and 420 crystal planes of $\mathrm{NaCl}$, respectively. These results can explain the fast loss of mass at the beginning of the bioactivity tests, which can be strictly related to the dissolution of $\mathrm{NaCl}$ in the liquid medium.

\subsection{Cytotoxicity studies}

MTT viability test was used to follow the behavior of the cells in the presence of $45 \mathrm{~S} 5$ or $45 \mathrm{~S} 5 \mathrm{~B}$ bioglasses, in order to determine the concentration to inhibit $50 \%$ of the metabolism of the cells $\left(\mathrm{IC}_{50}\right)$. The results for the samples extracted from $200 \mathrm{mg}$ of bioglass per milliliter of DMEM evidenced the typical feature of these materials, i.e., their dissociation capability in aqueous medium, increasing the osmotic force, leading the cells to die after $24 \mathrm{~h}$. The high ion concentration outside the cells resulted in the diffusion of water in an attempt to reach the osmotic equilibrium, leading them to plasmolysis [32]. The total metabolism inhibition was detected for both the bioglasses at $200 \mathrm{mg}$ $\mathrm{mL}^{-1}$. Studies at lower concentrations of bioglasses, ranging from 100 to $0.63 \mathrm{mg} \mathrm{mL}^{-1}$, led to the growth inhibition profile shown in Fig. 7, for which the $\mathrm{IC}_{50}$ values were 8.15 and $7.56 \mathrm{mg} \mathrm{mL}^{-1}$ for $45 \mathrm{~S} 5$ and $45 \mathrm{~S} 5 \mathrm{~B}$ (Fig. 7a), respectively. Figure $7 \mathrm{~b}$ shows the MTT results in which the low concentration of the bioglass gave rise to the intense purple color, indicating the activity of the enzymes from the alive cells in the conversion of MTT (yellow, shown in the positive control, CP) to its formazan derivative (purple, shown in the positive control, CP). The gradual decrease in color associated to the gradually increased bioglass concentration indicates the cell death in agreement with the concentration. These results showed the need of high concentrations of the bioglasses to inhibit 50\% of the cell metabolism, indicating their low cytotoxic effect.

In general, the results indicated the success of the sol - gel method for the preparation of 45S5B and 45S5 bioglasses from water-soluble salts. The characterizations revealed that the boron-based bioglass 45S5B prepared by sol-gel technology showed similar properties to the 45S5 bioglass, especially its capability of stimulating the deposition of hydroxyapatite at the surface. This property is the most important for the osteointegration in the bonehealing process, once the hydroxyapatite is the material that composes the bone. Thus, its deposition at the surface of the 45S5B bioglass improves its capability of integration with 
Fig. 7 a Cell viability (\%) after treatment with $45 \mathrm{~S} 5$ or $45 \mathrm{~S} 5 \mathrm{~B}$. b MTT results, showing the digital micrograph of the plate and two examples of optical microscopy images of the cells at 0.63 and $100 \mathrm{mg} \mathrm{mL}^{-1}$ of $45 \mathrm{~S} 5$ and 45S5B, respectively (cell dimension about $30 \mu \mathrm{m})$. NP $=$ negative control, $\mathrm{PC}=$ positive control
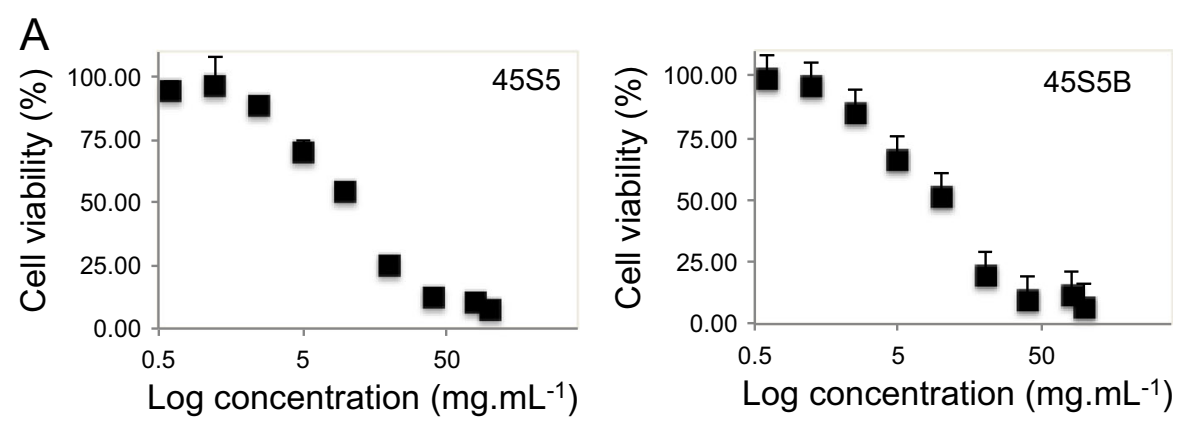

$B$ Controls Bioglass concentration (mg. mL-1)

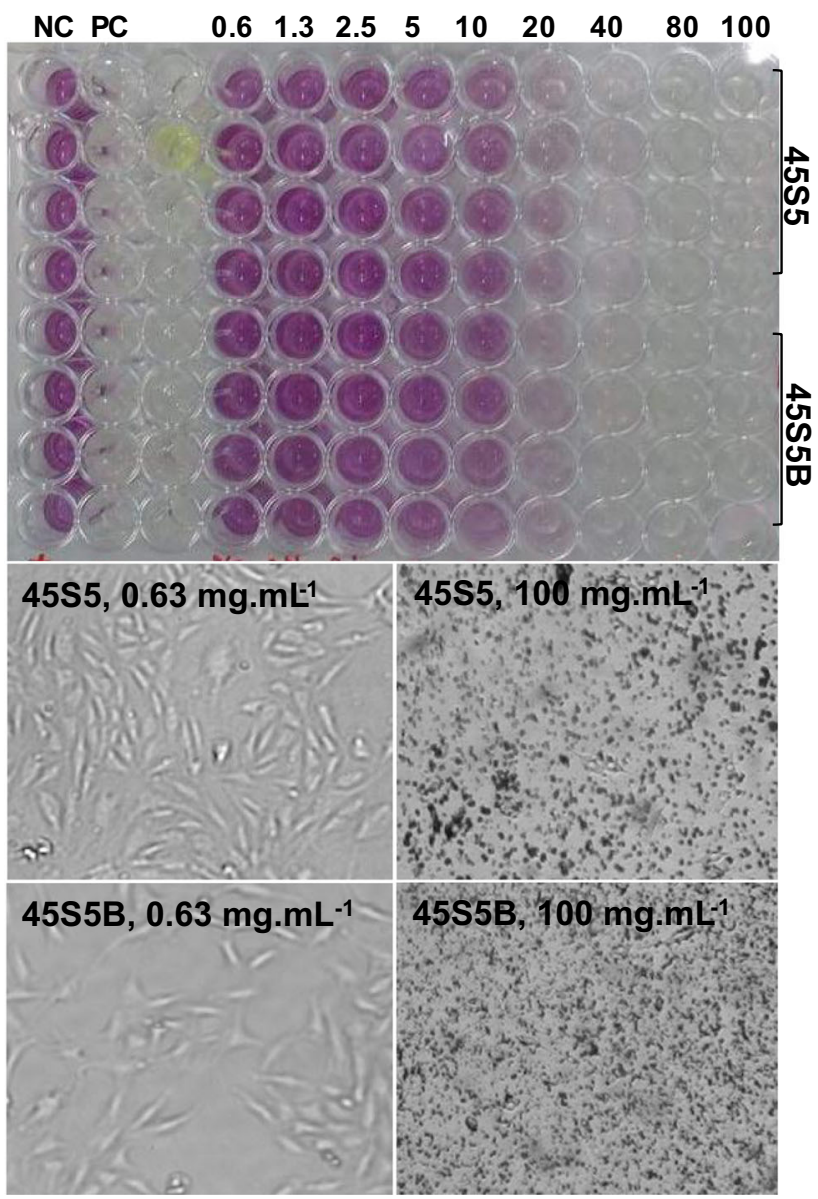

bone. In addition, the sol-gel technology and the watersoluble salts represent a potential alternative to the conventional method for the preparation of bioglasses.

\section{Conclusions}

The sol-gel process was successfully used for preparation of the boron-based 45S5B bioglass, as well for the preparation of the classical 45S5. The bioglass characterization showed the efficiency of the sol-gel process to generate this boron-based bioglass, usually prepared by heat treatment from oxides as starting material. The chemical structure was analyzed by ATR-FTIR spectroscopy before and after immersion in SBF to follow their behavior with respect to the formation of hydroxyapatite. The results indicated the formation of large amounts of hydroxyapatite, shown by the gain of mass for both $45 \mathrm{~S} 5$ and 45S5B in SBF and also by SEM images, indicating their high bioactivity. 45S5B showed a cytotoxic effect similar to $45 \mathrm{~S} 5$ under the tested conditions against eukaryotic OSTEO1 cells in vitro, a preliminary result that suggests it is safe for the development of its based materials for biological applications. 
Acknowledgements The authors acknowledge Capes for RGF doctoral fellowship, Fundação Nacional de Desenvolvimento do Ensino Superior Particular (FUNADESP), and University of Araraquara (UNIARA) for funding.

\section{Compliance with ethical standards}

Conflict of interest The authors declare that they have no conflict of interest.

\section{References}

1. Farr JN, Khosla S (2015) Skeletal changes through the lifespanfrom growth to senescence. Nat Rev Endocrinol. https://doi.org/ 10.1038/nrendo. 2015.89

2. Sheikh Z, Hamdan N, Ikeda Y, Grynpas M, Ganss B, Glogauer M (2017) Natural graft tissues and synthetic biomaterials for periodontal and alveolar bone reconstructive applications: a review Biomater Res 21:1-20

3. Habraken W, Habibovic P, Epple M, Bohner M (2016) Calcium phosphates in biomedical applications: materials for the future? Mater Today 19:69-87

4. Lanza RP, Langer RS, Vacanti J (eds) In Principles of tissue engineering (2014), Elsevier, San Diego, CA.

5. Rodella LF, Favero G, Labanca M (2011) Biomaterials in maxillofacial surgery: Membranes and grafts. Int J Biomed Sci 7:8188

6. Wenz B, Oesch B, Horst M (2001) Analysis of the risk of transmitting bovine spongiform encephalopathy through bone grafts derived from bovine bone. Biomaterials 22:1599-1606

7. Šupová M (2015) Substituted hydroxyapatites for biomedical applications: a review. Ceram Int 41:9203-9231

8. Hench LL, Splinter RJ, Allen WC, Greenlee TK (1971) Bonding mechanisms at the interface of ceramic prosthetic materials. $\mathrm{J}$ Biomed Mater Res 5:117-141

9. Hench LL (2006) The story of Bioglass ${ }^{\circledR}$. J Mater Sci: Mater Med 17:967-978

10. Shankhwar N, Srinivasan A (2016) Evaluation of sol-gel based magnetic 45S5 bioglass and bioglass-ceramics containing iron oxide. Mater Sci Eng C 62:190-196

11. Soubelet CG, Albano MP, Conconi MS (2018) Sintering, microstructure and hardness of Y-TZP- 64S bioglass ceramics. Ceram Int 44:4868-4874

12. Pazarçeviren AE, Tahmasebifar A, Tezcaner A, Keskin D, Evis Z (2018) Investigation of bismuth doped bioglass/graphene oxide nanocomposites for bone tissue engineering. Ceram Int 44:37913799

13. Vassilakopoulou A, Dimos K, Kostas V, Karakassides MA, Koutselas I (2016) Synthesis and characterization of calcium oxyboroapatite with bimodal porosity. J Sol-Gel Sci Technol 78:339-346

14. Kokubo T, Kim HM, Kawashita M (2003) Novel bioactive materials with different mechanical properties. Biomaterials $24: 2161-2175$

15. Lucacel Ciceo R, Trandafir DL, Radu T, Ponta O, Simon V (2014) Synthesis, characterisation and in vitro evaluation of sol-gel derived $\mathrm{SiO} 2-\mathrm{P} 2 \mathrm{O} 5-\mathrm{CaO}-\mathrm{B} 2 \mathrm{O} 3$ bioactive system. Ceram Int 40:9517-9524
16. Fu Q, Rahaman MN, Fu H, Liu X (2010) Silicate, borosilicate, and borate bioactive glass scaffolds with controllable degradation rate for bone tissue engineering applications. I. Preparation and in vitro degradation. J Biomed Mater Res-Part A 95:164-171

17. Hassan EA, Hassan ML, Oksman K (2011) Improving bagasse pulp paper sheet properties with microfibrillated cellulose isolated from xylanase-treated bagasse. Wood Fiber Sci 43:76-82

18. Yang X, Zhang L, Chen X, Sun X, Yang G, Guo X, Yang H, Gao C, Gou Z (2012) Incorporation of B2O3in CaO-SiO2-P2O5 bioactive glass system for improving strength of low-temperature co-fired porous glass ceramics. J Non Cryst Solids 358:11711179

19. Fu H, Fu Q, Zhou N, Huang W, Rahaman MN, Wang D, Liu X (2009) In vitro evaluation of borate-based bioactive glass scaffolds prepared by a polymer foam replication method. Mater Sci Eng C 29:2275-2281

20. Bi L, Rahaman MN, Day DE, Brown Z, Samujh C, Liu X, Mohammadkhah A, Dusevich V, Eick JD, Bonewald LF (2013) Effect of bioactive borate glass microstructure on bone regeneration, angiogenesis, and hydroxyapatite conversion in a rat calvarial defect model. Acta Biomater 9:8015-8026

21. Lin Y, Brown RF, Jung SB, Day DE (2014) Angiogenic effects of borate glass microfibers in a rodent model. J Biomed Mater ResPart A 102:4491-4499

22. Deliormanli AM (2013) Size-dependent degradation and bioactivity of borate bioactive glass. Ceram Int 39:8087-8095

23. Haro Durand LA, Vargas GE, Romero NM, Vera-Mesones R, Porto-López JM, Boccaccini AR, Zago MP, Baldi A, Gorustovich A (2015) Angiogenic effects of ionic dissolution products released from a boron-doped $45 \mathrm{~S} 5$ bioactive glass. J Mater Chem B 3:1142-1148

24. Shah FA, Czechowska J (2018) 9-Bioactive glass and glassceramic scaffolds for bone tissue engineering. In: Bioactive glasses, pp 201-233. Ed. Heimo Ylänen. Woodhead Publishing, Elsevier, second edition, Kidlington, UK, 2018. https://doi.org/10. 1016/B978-0-08-100936-9.00011-3

25. Balasubramanian P, Grünewald A, Detsch R, Hupa L, Jokic B, Tallia F, Solanki AK, Jones JR, Boccaccini AR (2016) Ion release, hydroxyapatite conversion, and cytotoxicity of boroncontaining bioactive glass scaffolds. Int J Appl Glas Sci 7:206215

26. Li R, Clark AE, Hench LL (1991) An investigation of bioactive glass powders by sol-gel processing. J Appl Biomater 2:231-239

27. Pirayesh H, Nychka JA (2013) Sol-gel synthesis of bioactive glass-ceramic 45S5 and its in vitro dissolution and mineralization behavior. J Am Ceram Soc 96:1643-1650

28. Kamitsos EI (2003) Infrared studies of borate glasses. Phys Chem Glas-Eur J Glas Sci Technol Part B 44:79-87

29. Kamitsos EI, Patsis AP, Karakassides MA, Chryssikos GD (1990) Infrared reflectance spectra of lithium borate glasses. J Non Cryst Solids 126:52-67

30. Ouis MA, Abdelghany AM, ElBatal HA (2012) Corrosion mechanism and bioactivity of borate glasses analogue to Hench's bioglass. Process Appl Ceram 6:141-149

31. Pham TTT, Nguyen TP, Pham TN, Vu TP, Tran DL, Thai H, Dinh TMT (2013) Impact of physical and chemical parameters on the hydroxyapatite nanopowder synthesized by chemical precipitation method Adv Nat Sci Nanosci Nanotechnol 4:1-9

32. Kültz D, Chakravarty D (2001) Hyperosmolality in the form of elevated $\mathrm{NaCl}$ but not urea causes DNA damage in murine kidney cells. Proc Natl Acad Sci USA 98:1999-2004 